\title{
Fighting Fascism with 'Verbal Bullets': Kaji Wataru and the Antifascist Struggle in Wartime East Asia
}

\author{
Edwin Michielsen \\ Department of East Asian Studies, University of Toronto, Toronto, Canada \\ edwin.michielsen@mail.utoronto.ca
}

\begin{abstract}
This article examines the cultural production of Kaji Wataru, founder of the Zaika Nihonjinmin hansen dōmei [Japanese People's Antiwar League in China] to illuminate what strategies Kaji used to train prisoners-of-war and to convert Japanese soldiers as a way to counter fascism during the second Sino-Japanese War (1937-1945). Scholars have tended to focus on unravelling the history surrounding Kaji Wataru and the Antiwar League. In doing so, they have often overlooked the constructive role his cultural works played in that history and in his antiwar thought. The author aims to show how Kaji's reportage works, and plays, were the very media he used to develop and execute his antifascist visions and activities. The focus is on three reportage works and one play that best reflect Kaji's antifascist strategies. Analyzing the texts, the author highlights descriptions dealing with the organization and activities of the Antiwar League as well as the cooperation with the Chinese resistance as part of the popular front in East Asia.
\end{abstract}

\section{Keywords}

Japan - China - antifascism - Kaji Wataru (1903-1982) - Sino-Japanese War - Zaika Nihonjinmin hansen dōmei - Japanese People's Antiwar League in China - War of Resistance literature

Concerning the literary movement, we can speak of the possibility of an antifascist popular front for the first time when we foresee the attacks of the enemy, the writers' alliance supports the organization and cooperates with the workers and farmers' arts alliance, and connects with other popular groups such as political parties and unions as a political front to stop the wave of fascism....

(C) EDWIN MICHIELSEN, 2020 | DOI:10.1163/22116257-09010006

This is an open access article distributed under the terms of the prevailing CC-BY-NC license at the time of publication. 
The party and labor unions which were supposed to be the pillars of resistance were on the verge of a terrible annihilation. In general, it was a time where the easily swayed social-democrats felt unease and fear, and without being able to raise their voices, they were pushed in the direction of cooperators with 'war and fascism'. Amongst them, ten or twenty small political groups gathered shouting proudly 'popular front'. To compare that to the popular front emerging as a real possibility of resistance against fascism in France and Germany is completely ridiculous....

Then, why did Japan lack such a possibility like Europe? What explanation can we think off regarding the absence of such a possibility?

Almost fifteen years after the Second World War, political activist and writer, Kaji Wataru (1903-1982), reflected on resistance against fascism in interwar Japan. Kaji concluded that the absence of an antifascist popular front in Japan had two causes. First, the complicated relationship between 'art and politics' within the proletarian literary movement led to numerous splits that subsequently divided the movement into several factions in the late 1920s and early 193os. ${ }^{2}$ From the movement's inception, proletarian artists debated whether art should be independent of politics. Unfortunately, the debates failed to crystallize into any kind of consensus, which activists, such as Kaji, considered necessary in order to form an antifascist popular front. Second, Kaji linked the absence of resistance against fascism to a broader historical context of capitalist development. For Kaji, capitalism developed in Japan without a sufficient democratic revolution; and therefore, lacked the conditions for an anti-imperialist ethnonational revolution similar to China. ${ }^{3}$ As a result, informed by

1 Kaji Wataru, Jidenteki na bungakushi (Tokyo: San'ichi Shobō, 1959), 19-2o.

2 For a historical overview of left-wing literature in Japan see George Tyson Shea, Leftwing Literature in Japan: A Brief History of the Proletarian Literary Movement (Tokyo: Hosei University Press, 1964).

3 The Xinhai Revolution ended the Qing Empire (1636-1911) which resulted in the founding of the Republic of China in 1912. The Guomindang [GMD; Nationalist Party] won the first elections and tried to establish a modern nation-state. However, the end of the empire had left a power vacuum filled by warlords and imperial powers colonizing parts of China continuously undermining GMD's rule. Further, the founding of the Chinese Communist Party (CCP) in 1921 created another oppositional force to the GMD as both struggled for national governance. Only with the growing treat of full colonization by the Japanese Empire from the 193 os onward, the GMD and CCP put their differences aside to form a united front to fight Japanese imperialism and fascism. 
Marxist analysis, Kaji considered democracy in Japan only partially developed, serving capitalism while maintaining feudal remnants. ${ }^{4}$

Likewise, in the same postwar essay, Kaji described an unevenness among proletarian literary movements worldwide. ${ }^{5}$ Kaji noted that all movements progressed similarly and influenced each other, but he wondered why movements in Japan and Germany retreated while flourishing in the Soviet Union and China. Comparing Japan and China, he concluded that the historical conditions and outcomes of the Meiji restoration (1868) and Xinhai revolution (1911) differed significantly, rather than the organization of the Japanese and Chinese proletarian literary movements, which both had similar goals. ${ }^{6}$ According to Kaji, uneven capitalist development led to different historical trajectories and subsequently to the emergence of a popular front in China, not Japan. ${ }^{7}$ Without a popular front in Japan, Kaji realized that staying in Japan was pointless and decided to escape to China to join the popular front.

In this article, I examine the cultural production of Kaji Wataru, founder of the Zaika Nihonjinmin hansen dōmei [Japanese People's Antiwar League in China; hereafter Antiwar League], to illuminate what strategies Kaji used to train prisoners of war (POWs) and to convert Japanese soldiers as a counter-fascist measure during the Sino-Japanese War (1937-1945). Scholars have tended to focus on unravelling the history surrounding Kaji Wataru and the Antiwar League. In doing so, they have often overlooked the constructive role his cultural works played in that history and in his antiwar thought. For example, Inoue Keiko, whose study is the most complete and detailed historical analysis of Kaji Wataru, mentions Kaji's cultural works only in passing as a supplement to Kaji's antiwar activities; rather than, as I shall argue,

4 Kaji, Jidenteki na bungakushi, 20. Kaji's conclusion was point of longstanding debates on the development of Japanese capitalism. The two dominant positions were the Kōza [Lectures] faction, including Kaji, who claimed a 'two-stage' theory considering the Meiji Restoration of 1868 an incomplete bourgeois revolution and thus leaving Japanese society with feudal remnants, and the Rōno [Labor-Farmer] faction, who argued that the Meiji Restoration was a successful bourgeois revolution and thus the Japanese society was ready for a proletarian revolution. For more on these debates see Gavin Walker, The Sublime Perversion of Capital: Marxist Theory and the Politics of History in Modern Japan (Durham, N.C.: Duke University Press, 2016), 28-44.

5 While Kaji was not able to publish most of his work in Japanese during the war, his views expressed in this postwar essay are based on his observations during the Sino-Japanese War.

6 Kaji, Jidenteki na bungakushi, 8.

7 Ibid., 225 . 
acknowledging these works as the very media Kaji used to develop and execute his antifascist activities. ${ }^{8}$

The underrepresentation of Kaji's cultural works is arguably due to the failure to recognize reportage as an art form - which covers the majority of Kaji's works - and the tendency to consider kangzhan wenxue [War of Resistance literature] as mere ideological propaganda. ${ }^{9}$ Recently, historians have begun to re-evaluate the cultural production of the War of Resistance. Chang-tai Hung has shown how popular culture was used to disseminate patriotic messages for war mobilization nationwide and how newspaper reportage as a mode of popular culture 'constituted powerful political calls for change in the social system.'10 While Hung focuses on the national context, Stephen MacKinnon and Pingchao Zhu underscore the international features of the War of Resistance culture, the latter also includes a brief historical overview of Kaji's activities. ${ }^{11}$

In my approach to re-evaluate Kaji's cultural works, I am informed by Charles Laughlin's study on Chinese reportage. Considering reportage 'to mean any deliberately literary nonfiction text that narrates or describes a current event, person, or social phenomenon', Laughlin reads Chinese reportage, including war correspondence, as 'vehicles for expressing or constructing consciousness.'12 Further, Barak Kushner's study has examined the antiwar propaganda by the Chinese Communist Party (hereafter CCP) with help of the Japanese communist Nosaka Sanzō $(1892-1993) \cdot{ }^{13}$ His study not only helps

8 Weishang Guizi[Inoue Keiko], Ludi Gen de fanzhan sixiangyufanzhan huodong (ChangchunShi: Jilin Daxue Chubanshe, 2008) also published in Japanese as Inoue Keiko, Chūgoku de hansen heiwa katsudō o shita Nihonjin: Kaji Wataru no shisō to shōgai (Tokyo: Yachiyo Shuppan, 2012). Besides Inoue Keiko, see Lü Yuanming, Bei yiwang de zaihua riben fanzhan wenxue (Changchun-shi: Jilin Jiaoyu Chubanshe, 1993); Yang Wenbin and Yin Zhantang, ed., Zaihua Riren fanzhan yundong jishi (Beijing: Jiefanjun Chubansha, 2015). The entire archive of the Antiwar League has been published in thirteen volumes as Kaji Wataru Shiryō Chōsa Kankōkai, Nihonjinmin hansen dōmei shiryō (Tokyo: Fuji Shuppan, 1994-95).

9 Senden in Japanese and xuanchuan in Chinese as translations of propaganda tend to have a more neutral connotation than in English. For a discussion of senden see Barak Kushner, The Thought War: Japanese Imperial Propaganda (Honolulu: University of Hawaii Press, 2006), 22-25, and for xuanchuan see Weihong Bao, Fiery Cinema: The Emergence of an Affective Medium in China, 1915-1945 (Minneapolis, MN: University of Minnesota Press, 2015), 300-306. Chang-tai Hung, War and Popular Culture: Resistance in Modern China, 1937-1945 (Berkeley: University of California Press, 1994), 10-11.

11 Stephen R. MacKinnon, Wuhan 1938: War, Refugees, and the Making of Modern China (Berkeley: University of California Press, 2008), 97-110; Pingchao Zhu, Wartime Culture in Guilin, 1938-1944: A City at War (Lanham, Md.: Lexington Books, 2015), 175-180.

12 Charles A. Laughlin, Chinese Reportage: The Aesthetics of Historical Experience (Durham: Duke University Press, 2002), 153.

13 Kushner, The Thought War, 128-147. Kushner also mentions Kaji's activities, 141-143. 
me to contextualize Kaji's own cooperation with the Guomindang [GMD; Nationalist Party], but also to understand his reportage and propaganda as an attempt to complicate the perception of Japanese soldiers as mere 'devils' blindly following fascist orders and to expose the deceptive rhetoric of Japanese propaganda. ${ }^{14}$ Building off Laughlin and Kushner's insights, I shall read Kaji's texts highlighting descriptions dealing with the organization and activities of the Antiwar League, as well as his cooperation with the Chinese resistance. In doing so, I aim to elucidate how Kaji's cultural works exemplify the War of Resistance as a transnational front with shared aesthetics linked by intricate connections to the worldwide antifascist struggle.

Among Kaji's works, I have chosen two reportage works and one play covering various spaces (POW camp, battlefield, and home front). Although Kaji wrote all works in Japanese, he could not publish them in Japan due to the severe censorship of proletarian writings; and instead, published (partial) translations in Chinese, targeting different audiences. Examining these works allows me to demonstrate how Kaji articulated the complexities and interrelations of these spaces and how he investigated the antagonism and disparity among East Asian peoples instilled by fascism. These works are: Heiwamuraki [Reportage of Peace Village] (1938), a reportage work based on his ideological education in a Pow camp; Warera Shichinin [We, Seven] (1940), a reportage work narrating his activities with members from the Antiwar League on the battlefront near the Kunlun Pass; Sankyōdai [Three Brothers] (1940), an antiwar theatre play narrating the story of the Miyamoto family broken apart by the war and struggling at the home front to find a way to deal with the war. ${ }^{15}$

\section{Exile in China}

Ever since Kaji discovered Lenin's The State and Revolution in Tokyo in 1925, he devoted a significant amount of his time to study the relationship between war, imperialism and capitalism, with a specific focus on the Japanese empire. ${ }^{16}$

14 Other important studies examining Japanese wartime propaganda and fascism are: Takashi Fujitani, Race for Empire: Koreans as Japanese and Japanese as Americans during World War II (Berkeley: University of California Press, 2011); Annika A. Culver, Glorify the Empire:Japanese Avant-Garde Propaganda in Manchukuo (Vancouver: UBC Press, 2013); Alan Tansman, The Aesthetics of Japanese Fascism (Berkeley, CA: University of California Press, 2009); Alan Tansman, ed., The Culture of Japanese Fascism (Durham: Duke University Press, 20o9).

15 The dates refer to the year Kaji wrote these works.

16 Kaji Wataru, Chügoku no jūnen (Tokyo: Jiji Tsūshinsha, 1948), 11-12. 
From the mid-192os onward, he matured from a militant student participating in the leftist cultural circles of Tokyo to a prominent theoretician, activist and writer of the nation-wide proletarian movement. ${ }^{17}$ Further, as an editor of the Musansha Shinbun [Proletarian Newspaper], Kaji actively published on imperial violence perpetrated by the Japanese empire. Among the various aggressive incidents toward China, Kaji considered the Manchurian Incident in 1931 the starting point for fascism to permeate mainstream society. ${ }^{18}$ During these first years of activism in the late 1920s, Kaji managed to avoid arrest and imprisonment, but with the increasing militarization and anti-leftist policies across the Japanese empire all proletarian members were targeted by the police. Soon after joining the Communist Party, Kaji was arrested and eventually incarcerated in 1934 for almost two years. ${ }^{19}$ Upon his release, Kaji found himself in a completely different reality. After massive repression and censorship, the last proletarian movements had dissolved and the government strictly regulated media, arts, and the publishing world throughout the empire silencing any form of opposition. Kaji decided to escape as he knew that staying in Japan was futile.

After he arrived in Shanghai, ${ }^{20}$ Kaji read the 1935 Georgi Dimitrov report. This report, delivered at the Seventh World Congress of the Communist International and titled, 'The Fascist Offensive and the Tasks of the Communist International in the Struggle of the Working Class against Fascism', discussed the importance of an international popular front against fascism. This report inspired Kaji to contribute to the growing resistance against Japanese fascism. It was only with the outbreak of the Sino-Japanese War that one of Kaji's friends, Max Granich (1896-1987), ${ }^{21}$ suggested to him that 'there is work for

17 For a detailed biographical overview of Kaji Wataru see Inoue's study. For Kaji's postwar activities see Esselstrom, Erik, 'From Wartime Friend to Cold War Fiend: The Abduction of Kaji Wataru and U.S.-Japan Relations at Occupation's End,' Journal of Cold War Studies 17, no. 3 (2015): 159-183.

18 Kaji, Chügoku no jünen, 14.

19 Inoue, Chügoku de hansen heiwa katsudōo shita Nihonjin, 16-18. Kaji was reluctant, like many other proletarian artists and activist, to join the Japanese Communist Party considering the orthodoxy counterproductive to their artistic projects.

20 Two years before Kaji's arrival in Shanghai, antiwar, anti-imperial, and antifascist groups and activist from all over the world gathered in Shanghai to participate in the Far East Antiwar Antifascist Convention held on 30 September 1933 hosted by Song Qingling. For a detailed collection of primary and secondary sources see Shanghaishi Sun Zhongshan Song Qingling wenwu guanli weiyuanhui and Shanghai Song Qingling yanjiuhui, ed., Yuandong fanzhan huiyi jinianji (Shanghai: Dongfang Chuban Zhongxin, 2014).

21 Max Granich, younger brother of communist writer Itzok Isaac Granich (1894-1967), who joined the Communist Party in the late 1920 and moved together with his wife Grace 
him to be done.' Granich advised that Kaji should focus on Japanese Pows, which he based on the news of the CCP's capture of many Japanese POws after the Battle of Pingxingguan (25 September 1937). ${ }^{22}$

The war forced Kaji out of Shanghai. However, with the help of local friends, he escaped to Hong Kong from whence he moved to Wuhan, which was the new base of the GMD government and many (communist) resistance activists. ${ }^{23}$ During his first years in China, Kaji gradually gained a position in the Chinese literary establishment, actively engaging with a number of prominent writers such as Feng Naichao (1901-1983), Guo Moruo (1892-1978), Xia Yan (1905-1995), Tian Han (1898-1968), and Hu Feng (1902-1985), all active in the resistance. With their help, Kaji frequently published his writings in Chinese newspaper and journals.

Following the start of total war between Japan and China, Kaji realized that Japanese Pows could play a crucial role in the GMD's struggle against Japan as valuable sources of information. However, residing in a GMD controlled area made it difficult for Kaji to organize his resistance activism due to ideological differences. After he received the right papers with the help of Song Qingling $\left(1893^{-1981}\right)^{24}$ to stay in Wuhan, he was assigned a position in the Japanese language division of the Disanting [Third Bureau] dealing with 'anti-enemy propaganda' led by Guo Moruo and many other proletarian writers.

Slowly settling in Wuhan, which had transformed into 'the center of the international antifascist front in the East' and been nicknamed 'Madrid of the

Granich (1895-1971) to the Soviet Union and China. In China, the couple engaged with Agnes Smedley, Rewi Alley, Song Qingling, and Kaji Wataru. They founded the journal Voice of China and were active in the resistance based in Shanghai. For more Max and Grace Granich, see Adalbert Tomasz Grunfeld, 'Friends of the Revolution: American Supporters of China's Communists, 1926-1939' (PhD diss., New York University, 1985), 179-214.

22 Kaji, Chügoku no jūnen, 52. Inoue, Chügoku de hansen heiwa katsudō o shita Nihonjin, 37-38. For a detailed account of Kaji's period in Shanghai see his Shanhai sen'eki no naka (Tokyo: Tōhō Shuppansha, 1974).

23 The Nationalist Government left their capital Nanjing following the invasion of the Japanese Imperial Army in Shanghai in 1937. They retreated to Wuhan but following the battle of Wuhan the government moved again to Chongqing.

24 Song Qingling was the wife of Sun Yat-Sen (1866-1925), the first president of the Republic of China, while her younger sister Meiling married Jiang Jieshi (Chiang Kaishek), Sun's successor. Song Qingling played a prominent role in Chinese politics siding with the communists throughout the Sino-Japanese War and the Chinese Civil War (1945-49). After the CCP's victory, she acted as a vice chairperson of the newly established People's Republic of China followed by various positions in the highest echelons of Chinese politics until her death in 1981. For more on Song Qing Ling see Israel Epstein, Woman in World History: Life and Times of Soong Ching Ling (Mme. Sun Yatsen) (Beijing: New world Press, 1995). 
East', ${ }^{25}$ Kaji started his anti-imperial and antifascist activities. Together with the other members of the Japanese language division, Kaji's initial tasks were to monitor Japanese radio broadcasts and gather vital information to be sent to the GMD and CCP offices. Further, he collected Japanese newspapers and magazines smuggled through Hong Kong and translated documents confiscated from Japanese Pows and fallen soldiers. Lastly, he published antiwar leaflets and broadcasted antiwar speeches in Japanese on the radio. As his contact with Pows increased, he gradually shifted toward educating Pows.

Informed by the Geneva Conventions protecting the rights of Pows, both the GMD and CCP adopted their own POW regulations to accommodate the first groups of Japanese Pows following the battles of Shanghai (August-November 1937), Tai'erchuang (March-April 1938), Xuzhou (May 1938), and Wuhan (JuneOctober 1938). ${ }^{26}$ In 1938, Kaji together with his wife Ikeda Yukiko (?-1973), antiwar activist and fluent in Chinese, met with two Japanese Pows at a temporary Pow camp in Wuhan. At this meeting, Kaji learned that Japanese soldiers, like these Pows, fought in the war not on the basis of fascist ideology, but due to poverty. ${ }^{27}$ The treatment of Pow's as 'war trophies' and their miserable conditions galvanized Kaji to formulate an action plan to educate POWs. ${ }^{28}$ In order to execute his plans, Kaji had to gain the approval of generalissimo Jiang Jieshi (Chiang Kai-shek, 1887-1975). Prior to the new POw regulations, the GMD had no standardized protocol for POW treatment, resulting in frequent killings, robbing, and burning of Pows and their belongings. ${ }^{29}$ Kaji wrote a report to Jiang describing his experience with the pows he had met, as well as outlining an education plan that would allow the Chinese forces to use pows as sources of

25 Kaji Wataru, Kaisōki 'Kōnichi sensō’ no naka de (Tokyo: Shin Nihon Shuppansha, 1982), 179.

26 The GMD published a set of regulations concerning Japanese pows titled 'Fulu chuli guiding' [Instructions for the Treatment of POWs] on 15 October 1937. Ten days later, the CCP responded with an edict 'Duiyu Rijun fulu de wenti' [About the problem of Japanese Pows] protecting the rights of Japanese Pows. A crucial difference was that only the CCP provided financial support to repatriate Pows to Japan. Inoue, Chūgoku de hansen heiwa katsudōo shita Nihonjin, 65-66. For a discussion of Japanese Pows in the CCP controlled areas see Margaret (Penny) B. Denny, 'Chinese Communist Mobilization of Japanese Pows in Yan'an, 1939-1945,' in Resisting Japan: Mobilizing for War in Modern China 1935-1945, ed. David Pong (Norwalk, CT: EastBridge, 2008), 127-174. For a discussion of the abovementioned battles, see Hans van de Ven, War and Nationalism in China, 1925-1945 (London; New York: Routledge Curzon, 2003), 211-227.

27 Kaji, Kaisōki "Kōnichi sensō” no naka de, 198-199.

28 Kaji Wataru, Heiwamura-ki (Tokyo: Chūō Kōronsha, 1947), 18-19, and Kaji Wataru, Hi no gotoku: Kaihō e no michi (Tokyo: Kōdansha, 1958), 66-71.

29 Kikuchi Kazutaka, Nihonjin hansen heishi to nitchū sensō: Jūkei kokumin seifu chīki no horyo shūyōjo to kanren sasete (Tokyo: Ochanomizu Shobō, 2003), 14. 
intelligence and vehicles of propaganda. In his report, Kaji requested that the Chinese authorities distinguish between the active aggressors and common soldiers; henceforth, treating the common soldiers well in order to extract useful information..$^{30}$ As a result, Kaji, together with Ikeda Yukiko, were granted permission to visit and educate the first Pow camp Heiwamura [Peace Village] in Changde, Hunan in early October 1939.

\section{Reporting Pows in Camp Peace Village}

Based on his observations of and conversations with pows, Kaji wrote Heiwamura-ki [Reportage of Peace Village], of which about half was translated into Chinese and published in installments in Jiuwang Ribao [Salvation Daily], a CCP-run newspaper edited by Xia Yan targeting a broader Chinese readership beyond the party. ${ }^{31}$ Reportage of Peace Village was the first of several reportage works Kaji wrote during his years in China. His choice for reportage as the format to convey the situation of the Pows to his audience corresponds to a trend within proletarian literature both in East Asia and elsewhere originating in the 1920s. Kaji's considered reportage literature to be born out of the daily lives of the proletariat and capable of exposing social inequalities as accurately as a photograph. ${ }^{32}$ According to Laughlin, such claims of reportage's veracity 'creates new possibilities for imaginative literary expressions' as opposed to literary fiction, because reportage allows for 'the exploration of modes of consciousness and identity other than individuality and a shift of focus in the production of meaning from characters to places and events. ${ }^{33}$ Exploring such new possibilities, proletarian writers like Kaij preferred reportage over literary fiction to write agitational reports about places and events during the SinoJapanese War. Writing reportage during a period of 'thirst for war coverage', ${ }^{34}$ Kaji was among the war correspondents who 'represented a new type of correspondent who challenged traditional journalistic practices, redefined the role

30 Inoue, Chügoku de hansen heiwa katsudō o shita Nihonjin, 69.

$31 \quad$ Kaji could not publish the Japanese manuscript until the end of the war and after he returned to Japan where he published it in 1947. For more on the Salvation Daily see Pingchao Zhu, Wartime Culture in Guilin, 50-54.

32 Kaji Wataru, 'Hōkoku bungaku to keishiki,' Asahi Shinbun, February 25-28, 1931, Morning edition. See also Kaji Wataru, 'Kiroku bungakuron,' in Puroretaria Geijutsu Kyōtei 4 (Tokyo: Sekaisha, 1930), 321-334.

33 Laughlin, Chinese Reportage, 3.

34 Parks M. Coble, China's War Reporters: The Legacy of Resistance Against Japan (Cambridge, Mass.: Harvard University Press, 2015), 6. 
of a reporter, created a new language, and, most important, ... attempted to reach a wide audience. 35

Reportage of Peace Village opens with the Chinese leadership and pows welcoming Kaji to Peace Village and introducing Peace Village to him not as a prison camp but rather as a 'new world' (atarashii sekai) and 'residents' council' (jichikai). Despite the previous leadership's mandate to enforce the GMD ideology of Sanminzhuyi [Three Principles of the People] ${ }^{36}$ upon the 130 'villagers' (murabito), ${ }^{37}$ the ensuing leadership implemented a strategy based upon mutual understanding, discussion, and education. Learning of this more progressive POW management strategy, Kaji envisioned 'a hopeful future' and saw 'ambition and ideals' in the village. ${ }^{38}$ For Kaji, the village and villagers were a miniature society imbued with a potential to experiment with new forms of social organization not possible within the Japanese empire. This experiment allowed Kaji to envision a framework for a revised political structure in postwar Japan.

In Reportage of Peace Village, Kaji noted the diversity and complexity of village society: ethnically - Korean, Japanese and even Russian, political ideologies ranging from military hard-liners to socialists, class differences amongst farmers, workers, traders, and various military ranks, and the inclusion of wives and comfort women amidst the predominantly male population. ${ }^{39}$ The inequalities embedded in the Pow population of Peace Village presented enormous challenges to Kaji in terms of fostering mutual understanding and increasing class consciousness and the Marxist interpretation of war. Kaji explores the POw camp as a place where opposing ideological groups mingle, presenting encounters of exchange and opportunities for a shared resistance against imperialism and fascism. Not without adversities and obstacles, Kaji aimed to educate the Pows about the causes and dangers of the current imperial war and to nurture mutual understanding among the Pows by laying bare

35 Chang-tai Hung, War and Popular Culture, 151. For Japanese war correspondence, the First Sino-Japanese War (1894-95) and the Russo-Japanese War (1904-05) were crucial in shaping the profession.

36 Three Principles of the People is a political philosophy developed by Sun Yat-sen (18661925) referring to nationalism, democracy, and the livelihood of the people which formed the basis of GMD ideology.

37 The leadership preferred to call Pows 'villagers'rather than prisoners.

38 Kaji, Heiwamura-ki, 16-18.

39 Ibid., 28-30. Kaji does not use the word 'comfort women' and the supervisors told him that the Korean women are spouses of traders in the war areas. Inoue Keiko adds 'comfort women' to the pows kept at Peace Village. 
their conflicting positionalities. For Kaji, it was important that Pows were not to be divided into groups. He writes:

Who is our enemy? It is the fascists. Now, in front of our eyes, we see the prison walls in the hearts of people erected by the fascists. Overcoming such distorted feelings must be difficult. There is a huge gap between me and them. That is not all. They are pushed into misery without any assurance. In that misery, they have restrained each other, searched for human kindness in each other, and isolated each other. Between Japanese and Koreans, between soldiers and traders, between hunchbacks and youngsters.

Separating these people with (our) power is easy. However, first putting them together, letting them understand each other, and letting them help each other is (our) priority. It might be difficult, but we should not avoid it. ${ }^{40}$

Responding to supervisor Liu's proposal to separate the 'stubborn' from the 'valuable', Kaji instead wanted the Pows to clash with each other rather than to avoid any confrontation. Behind this strategy was Kaji's belief that such clashes would contribute to convincing 'the stubborn' of their wrong. The Chinese supervisors were therefore an indispensable aid to Kaji, especially as several had studied in Japan and knew Japanese. Together with them, Kaji connected with many pows and made significant progress in educating them. Ultimately, his encounters with Pows collected in Reportage of Peace Village laid the foundation for Kaji's subsequent antiwar activities in Southern China from 1940 to 1941. Moreover, after his visit to Peace Village, Kaji convinced Jiang and other GMD leaders that using POWs for antiwar activities and propaganda proved successful in the case of Peace Village, encouraging the GMD to expand the number of Pow camps and antiwar education campaigns. They allowed Kaji to establish an antiwar branch in Guilin from where he and the other members directly sought contact with Japanese soldiers to persuade them to relinquish fighting.

After his arrival in Peace Village, Kaji immediately started to meet with villagers individually or in small groups, often upon request of the villagers themselves. The more stories he heard from villagers, the more he realized that a considerable challenge awaited him. The villagers were mentally broken due to the horrific experiences of the war and the shame they felt about being captured by the enemy. The Japanese military explicitly instructed its 
soldiers to refrain from falling in enemy hands; and instead, advised them to commit a heroic suicide. Therefore, many villagers still preferred to commit suicide to avoid the shame they imposed not only on themselves, but also their battalion and their families. Others, especially those referred to as the political and military 'hard-liners', distrusted Kaji, seeing him as a traitor and an enemy of the state with communist and revolutionary intentions. These hard-liners remained true to their imperial beliefs and often intimidated other villagers for expressing anti-imperialist views. Nevertheless, Kaji tried to discuss the contemporary issues related to the current war with them in an attempt to undermine their conservative views; and in turn, develop an inclusive space open to competing viewpoints, especially those that supported doubts about the war.

Kaji soon discovered that almost half of the villagers were Koreans. These Koreans were not soldiers, but traders operating in China proper or refugees escaping from Japanese imperialism. ${ }^{41}$ Chinese guerillas had captured them mistaking them for Japanese. It was easier for Kaji to talk with these Koreans because they bore a strong antagonism toward Japanese imperialism and the war. He was sympathetic to their situation and was willing to request provisions from the GMD leadership for their release following proper investigation into their claims of innocence.

The ethnic and gender differences also caused tension amongst villagers. Halfway through his stay, a Korean female villager requested a conversation with Kaji. She explained to him the heavy burden experienced by Koreans in the village. The woman herself had lived in Osaka during her childhood for nine years where Japanese always othered her as the 'Chōsenjin'[Korean], which Japanese settlers continued to call her even after her return to the Korean peninsula. The severe ethnocentrism within the Japanese empire motivated her and her husband to escape to China, where they unfortunately were met with further misunderstanding and maltreatment, discovering that the Chinese also considered them Japanese subjects. In addition to imprisonment, Japanese villagers in Peace Village bullied them. For example, the woman told Kaji about the 'flag incident'. The village planned a party where they intended to symbolize the friendship among the 'Peoples in the East' using the three national flags of Japan, China, and Korea. However, prior to the official ceremony, the Korean flag was marked with graffiti reading ' $h$ i no maru' [name of the Japanese flag], suggesting that Korea was a Japanese colony, not an independent state. In

41 The Japanese empire started conscripting colonial volunteer soldiers from 1938 and installed mandatory conscription in 1944. 
addition to this insult, Japanese hardliners joked: 'Does Korea have a flag? I have never seen it.' ${ }^{2}$ This incident created further animosity between Japanese and Koreans, challenging the entire nature of Peace Village.

Following the conversation with the Korean woman, Kaji visited three Korean men to discuss possible solutions for this ethnic tension in the village. Yi So-rim, one of the Korean men, shares his story with Kaji:

Koreans cannot live in Korea any longer. However, if oppressed they leave their country, and then they are a pitiful nationality without a native land. Besides, whenever and wherever, the shadow of Japanese imperialism comes to oppress.... Where is a place for Koreans to live in peace? Is our fate always going to be like this?... I paid for my own schooling. And I found a small job at a town hall. But in a society controlled by Japanese I understood immediately that there is no future in which we can live. I left and started a business. However, there was no free world. On the contrary, it was seized by imperialism. ${ }^{43}$

In response, Kaji expressed his hope for an independent Korea after the war, 'where the Korean flag will wave'. Conversely, the Koreans villagers struggle to imagine such as future as the ubiquitous Japanese empire has been terrorizing the Koreans for almost forty years. ${ }^{44}$ Despite, their disheartened attitude, Kaji encouraged the Koreans to cooperate in village discussion as they understood the oppression of Japanese imperialism through lived experience. Unlike their Japanese counterparts who had been indoctrinated by a militaristic and fascist education for decades, Kaji emphasized that all villagers are victims, but the problem is that the Japanese fail to realize that they themselves are also victims due to their persistent patriotic sentiment; a sentiment that explains their victimhood in terms of sacrifice for the nation. ${ }^{45}$ Thus, Kaji maintained his belief that educating the villagers was the only method to nurture mutual understanding and respect.

Besides asking for their cooperation, Kaji also informed the Koreans about the possibility of joining the Korean volunteer army. ${ }^{46}$ Kaji's support of

42 Kaji, Heiwamura-ki, 293.

43 Ibid., 300.

44 The disappearance of any future imagination of Korea expressed by Yi resonates with what Janet Pool has examined as a new temporal sense in late colonial works of Korean writers living on the Korean peninsula. Janet Poole, When the Future Disappears: The Modernist Imagination in Late Colonial Korea (New York: Columbia Univ. Press, 2015).

45 Kaji, Heiwamura-ki, 298.

46 For a discussion of anti-imperial Koreans groups active in China see chapter 6 in Uchida Tomoyuki, Kōnichi sensō to minshū undō (Tokyo: Sōdosha, 2002), 243-278. 
national volunteer and liberation armies displays his vision of a popular front made up of groups maintaining their independence. His vision directly contrasted that of Aoyama Kazuo (1907-1997), another antiwar activist located in China proper. ${ }^{47}$ Inspired by the antifascist army in Spain, Aoyama preferred a communist front of East Asians focused on the destruction of Japan's emperor system. Kaji, however, supported the resistance organization along national lines, such as the Taiwanese, Korean and Japanese liberation armies, who cooperated in their fight against a shared enemy. ${ }^{48}$ Unlike Pow camps, where ethnic tensions were contained and controlled, Kaji stressed the importance of an effective and strong popular front and therefore was willing to support resistance groups based on ethno-nationality. ${ }^{49}$ While Kaji later wrote that he compromised his internationalism with the GMD's policies - the latter considered communist internationalism a threat to their ideology of ethno-nationalism - arguably it might also have contributed to undermining Japanese

47 Aoyama (real name Kuroda Zenji) aimed to organize an international volunteer army consisting of volunteers from East and Southeast Asia following the antifascist international volunteer army in Spain. In 1938, he established the Gokutō hanfassho dōmei [Far East Antifascist League] and met Kaji in Southern China at the Research Institute for International Affairs. Together with the leader of the Korean Volunteer Army Kim Yaksan (Kim Wonbong, 1898-1958) they discussed the organization for a popular front. However, both Kaji and Kim preferred to grant autonomy to each resistance group rather Aoyama's plan for a broad Far East League. Kaji and Kim's strategy was also a way to be more in line with the GMD and to receive their funding. In Reportage of Peace Village, Kaji tells a Japanese Pow that an international popular front has yet to be established and currently various resistance groups from Taiwan and Korea are cooperating with the Japanese and Chinese resistance. Kaji, Heiwamuri-ki, 232. For more on Aoyama see Aoyama Kazuo, Bōryaku jukurenkō (Tokyo: Myōgi Shuppan, 1957), and Kuroda Zenji, Hansen seiryaku Chügoku kara mita Nihon senzen senchū sengo (Tokyo: Misaki Shobō, 1972).

48 Kikuchi mentions the following resistance groups active in China: The Japanese Antiwar Alliance, The Korean Volunteer Army, The Korean Youth Battlefield Operation, The Taiwanese Federation of Revolutionary Organizations. Kikuchi, Nihonjin hansen heishi to nitchū sensō, 62. For an extensive list of Japanese antiwar groups active in the CCP occupied areas see Inoue, Chügoku de hansen heiwa katsudō o shita Nihonjin, 132-133.

49 Kaji, Chügoku no jünen, 77-80. Kaji writes that the generals and bureaucrats of the GMD government limited the organization of their party to a 'feudal ethno-nationalism' and lacked any international spirit. While the Antiwar Alliance established good relations with groups such as the Korean Volunteer Army, the right-wing clique in the Chongqing government worked against any international cooperation, especially following the deteriorated relation between the GMD and CCP. For a history of these GMD right-wing cliques before the SinoJapanese War see Maggie Clinton, Revolutionary Nativism: Fascism and Culture in China, 1925-1937 (Durham: Duke University Press, 2017). 
imperial rhetoric of the Pan-Asianism by granting full independence to Asian liberation struggles. ${ }^{50}$

Besides the Koreans and hard-liners, Kaji also met several Japanese Pows who were sympathetic to his cause. For example, the soldier Mibune (first name not given) offered his help to Kaji. Although Mibune told Kaji that he did not share his communist ideology, he firmly opposed the fascist military leadership and worried about the future of Japan. Kaji decided to start a few private educational sessions with Mibune to explain to him the basics of the current war from a Marxist perspective. Mibune became Kaji's informant, sharing village intel and improvement strategies. Kaji asked Mibune to initiate similar discussions to those they had shared in order to encourage other villagers to exchange their war experiences. Further, he prepared Mibune to continue his antiwar activities within the village after Kaji had left. Educating pows like Mibune, Kaji epitomized Chinese propaganda promising Japanese soldiers humane treatment, forming a serious threat to the Japanese authorities, of which the latter was well aware. ${ }^{51}$

Reportage of Peace Village is first and foremost Kaji's attempt to show that Japanese soldiers are victims of what his colleague Xia Yan called the 'fascist bacteria'. It offers a glimpse into the challenges faced by antiwar activists, such as Kaji Wataru. During his two-week stay in Peace Village, Kaji met with many villagers, learning about their worldviews and the impact of the war on their lives. He portrayed a rich account of various individuals trying to make sense of their realities during wartime. Kaji penned these stories of mentally broken soldiers forced into war, urging Chinese readers to complicate their views of war and to distinguish the actual enemy from the apparent enemy. Repeatedly, Kaji presented his narrative of common Japanese folks as victims of the war to inform the Chinese resistance that bridges needed to be built among peoples across East Asia and beyond in order to dismantle the fascist rhetoric incited by the Japanese empire and foster international cooperation.

50 Opposition to Stalin's theory of 'Socialism in One Country' might also have played an important role. In the late 1920 and early 1930s, Korean communist parties and proletarian movements had to merge with Chinese and Japanese counterparts creating tension among members.

$5^{1}$ For a discussion of the Japanese's reception of Chinese propaganda see Kushner, The Thought War, 128-131. Prolific Japanese newspapers, such as Asahi Shinbun and Yomiuri Shinbun, frequently reported about Kaji's activities condemning him a 'national traitor' (baikokudo). 


\section{Firing 'Verbal Bullets' at the Frontline}

Kaji returned to Wuhan where he started his preparations for the establishment of the Antiwar League. He managed to convince Jiang Jieshi to provide him permission for his league and founded the Antiwar League in Guilin in November 1939 together with eleven members selected from the local pow camp Sosei Gakuen [Resurrection Academy].

Extracting eleven members from Sosei Gakuen and placing them in a special facility, Kaji began a thorough training program in order to prepare the members for antiwar activities on the battlefield. Kaji developed a daily schedule for the members, whereby they woke up at 6:0o a.m. to engage in physical exercise and alliance songs to strengthen their comradery and revolutionary spirit. The members were then engaged throughout the day in several educational activities, such as: studying Chinese, writing leaflets or contributions for their journal Jinmin no koe [Voice of the People], ${ }^{52}$ and participating in discussion groups. ${ }^{53}$ Kaji also organized study groups where they read texts, such as Nosaka Sanzō's Letters to Japanese Communism, Stalin's Report on the Work of the Central Committee to the Eighteenth Congress of the C.P.S.U. dealing with international affairs, and Lenin's Imperialism. Educating former Japanese soldiers, Kaji anticipated that these members could connect best with their former colleagues on the battlefield.

After a month, the Antiwar League moved to the battlefield surrounding the Kunlun Pass to launch 'verbal attacks' using voice amplifiers and megaphones. Through propaganda campaigns, they aimed to confront the Japanese soldiers with the realities of war and persuade them to desert. During his year at the battlefront, Kaji wrote two reportage works both translated and published in Chinese available for a general readership. ${ }^{54}$ The first work Warera shichinin [We, Seven] centers around Kaji's observations of war and the activities of the Antiwar League's propaganda unit. The second work, Kotoba no dangan [Verbal Bullets] is a collection of five letters sent to the antiwar division in Chongqing reporting on their activities at the frontline.

Kaji opens We, Seven with the Antiwar League preparing for their visit to the frontline during the Battle of Kunlun Pass (18 December 1939-11 January 1940).

52 The journals published by the Antiwar Alliance are reprinted in Kaji Wataru and Shiryō Chōsa Kankōkai, Nihonjinmin hansen dōmei shiryōNihonjinmin hansen dōmei shiryō.

53 Inoue, Chūgoku de hansen heiwa katsudō o shita Nihonjin, 95.

54 Chinese translations by Shen Qiyu and Zhang Ling'ao were published as Women qigeren (1943) and Jizi huoxianshang de xin (1945). After the war in 1947 Kaji published the Japanese manuscripts of We Seven and Verbal Bullets. 
On their way to the battlefield, crossing the Chinese military defense line, Kaji is baffled by the farmers working in the field, oblivious to the surrounding war. Kaji's surprise by the apparent bucolic landscape is short-lived as it is quickly juxtaposed by an approaching Chinese military defense line. Kaji's ability to communicate in common script to the soldiers with his message - 'I am an anti-imperialist. We are brothers.' - immediately shifts the attitude of the soldiers from one of condemnation to comradery. ${ }^{55}$ Kaji and his Antiwar League are welcomed by the soldiers with food and drinks. Kaji's talent to connect with both Japanese and Chinese soldiers allows him to immerse himself in the war environment, which he expresses as: locations overflowing with a wartime feeling depending on the place. ${ }^{56}$ Initially the war appeared to Kaji as fragmented and disconnected from spaces not subsumed into the temporality of war. For Kaji, then, it was a challenge to present these spatial and temporal fissures as interlocked through war.

Frequently visiting the basecamp and frontline, Kaji gradually unfolds an understanding of how seemingly disparate spaces, such as the pow camp and battlefield, are interconnected. He writes that: " $[\mathrm{w}] \mathrm{ar}, \ldots$ is a colossal fluctuating thing. Those on the battlefield can only see it partially. For example, the evening at hill 6o, even though one can see the whole, it is only a meaningless whole twinkling with sparks here and there. People are easily deceived and puzzled. ... It's about understanding the battlefield. That is what we must study. ${ }^{\prime 57}$ For the first time, Kaji realizes the deep impact that war has on the human psyche. Trying to grasp war in its entirety, he informs the readers of its complexities. While Japanese imperial media focus on romanticizing battles and the front, Kaji invites readers to consider the realities of pow camps, basecamps, and home fronts as the everyday lived experiences of war.

While Kaji slowly adjusts to the war environment, he and his team start to prepare their antiwar activities. They actively engaged in translating documents and Japanese radio broadcasts and, preparing leaflets and collecting war diaries and letters from dead soldiers. The latter proved useful in showing doubts and fears of soldiers undermining Japanese propaganda of heroism. Besides such activities, an essential activity of the Antiwar League was to transmit antiwar messages and lectures in the direction of the Japanese bases

55 Sinographs are mutually intelligible in writing for Japanese and Chinese, especially in Kaji's time before the significant script revisions of the postwar.

$5^{6}$ Kaji Wataru, Warera wa shichinin (Tokyo: Chūō Kōronsha, 1947), 20.

57 Ibid., 75 . 
through a voice amplifier and megaphone. ${ }^{58}$ After significant sounds tests, the team hid in the mountains 400 meters away from a Japanese military base. The Chinese officer informed the Chinese soldiers that the Japanese speech was from an ally so as not to alarm them. Kaji's antiwar speech is as follows:

Fellow comrades! Fellow comrades! I am actually Japanese. I am one of your comrades! Comrades! I am a Japanese who prays together with comrades and (our) ancestral land that faces unhappy and horrifying depths, and I fight to rescue that. We are the Japanese People's Antiwar Alliance. Today, I will tell you the dazzling truth.

Here are many Japanese comrades among the Chinese soldiers. Among these Japanese, many are like you soldiers. They have been deceived like you have to fight for the Japanese army. Unfortunately, they were wounded and made into Pows. They have been cordially liberated by the Chinese army and received medical treatment. Now, everyone is okay. Further, this war is actually an aggressor war planned by the military authorities. We know that the peoples of both countries are victims of that [war] and they dragged Japan in such a misfortunate war. In order to fight the military authorities disturbing peace in the East and eliminating the peoples of both countries, and in order to liberate the Japanese people, we have established here the Antiwar Alliance....

The resistance war is a resistance against the invaders who crush the peoples in the East and sacrifice the Japanese people and is all the more a friendly joining hands against a shared enemy by the people of both countries. ${ }^{59}$

Kaji opens his speech with references to his nationality and the 'ancestral land' (sokoku) mimicking the rhetoric of the empire to attract the attention of Japanese soldiers. Then, he diverges from this rhetoric into an analysis of war itself, laying the blame on political and military authorities, appealing to the victimhood of demoralized Japanese soldiers. Although Kaji avoids any direct references to previous ideas of proletarian internationalism, his final words calling for a shared front of East Asians against Japanese imperialism echoes messages of solidarity frequently used by proletarian movements a decade earlier. Kaji refers to the amplified utterances as 'verbal bullets' (kotoba no dangan) or 'voice bullets' (koe no dangan) that they 'fire at the hearts of the

$5^{8}$ Kushner mentions similar activities executed by antiwar Japanese POw groups working for the CCP. See Kushner, The Thought War, 131-132.

59 Kaji, Warera wa shichinin, 82-83. 
soldiers'. However, their bullets are not lethal, but instead are used to agitate the Japanese soldiers into a state of mutiny.

The Antiwar League continued to use the megaphone at the frontline, improving their antiwar propaganda with each new broadcast. Kaji's other reportage work, Kotoba no dangan [Verbal Bullets], written after the Battle of Zaoyang-Yichang (1 May 1940-18 June 1940) and during their visit to the Yichang Front in December 1940, reveals a detailed account of their propaganda campaigns. Here, they designed special programmes both to entertain and to inform Japanese soldiers at the front. An example of their programme looks as follows:

1. Welcome by Kaji.

2. Entertainment program by Nakamura and Takano.

3. End of the year agitation speech by Sasaki.

4. Manzai [comedy act] titled 'People's revolution' by Kishimoto and Nitta

5. Entertainment broadcast.

6. Concluding remarks by Kaji. 60

The program contained not only antiwar propaganda, but also entertainment, songs, and music to ease the minds of Japanese soldiers and develop a level of intimacy and trust. In his study on imperial propaganda, Kushner shows how the Japanese authority and military used similar forms of entertainment and comedy performances, such as rakugo and manzai, to mobilize domestic support for the war and to amuse the imperial troops abroad. ${ }^{61} \mathrm{~A}$ crucial difference between the two contesting forms of entertainment was that with the fading success of Japan's war efforts, Japan continuously had to invest in censorship concealing the horrors of war and deteriorating quality of the daily lives of ordinary Japanese, while Kaji and his members focused on exposing Japan's lies and portrayed with great honesty the daily reality soldiers and the home front all knew.

\section{Staging Antifascist Resistance: Kaji's Play Three Brothers}

Apart from reportage works, Kaji also wrote fiction, poems, and plays during his exile in China. Most notably among these works is his antiwar tragedy

6o Kaji Wataru, Kotoba no dangan (Tokyo: Chūō Kōronsha, 1947), 121-122. An example of a manzai presented to the Japanese soldiers using the microphone is as follows: 'If the war was over, I would like to go to my hometown / How can you go home? How? / If I knew how then there would be nothing to worry about.' Kaji, Kotoba no dangan, 93.

61 Kushner, The Thought War, 85-116. 
Sankyōdai [Three Brothers] (1940). For Kaji, reportage was a useful genre in terms of conveying a more accurate and objective account of the war than drama; however, literary performances could reach a much larger audience, particularly the largely illiterate Chinese population. Kaji wrote Three Brothers, like his other works, in Japanese. Without having a venue to publish Japanese language materials, however, he had his play translated in Chinese and performed for a Chinese audience different from his intended Japanese readership. Perhaps one of the reasons that Three Brothers was so successful when first performed at the Xinhua Theater in Guili, attracting seven thousand people in five days, was due to its ability to connect with a more diverse audience. ${ }^{62}$

Three Brothers portrays the daily life of family of Japanese workers who are impacted by the hardships of war. The narrative is raw and underdeveloped due to Kaji having to write the play in just three days in order to meet the deadline of an Antiwar League fundraiser. ${ }^{63}$ The depiction of the three Miyamoto brothers is flat, but conveniently situated in opposition to one another so as to represent various views of war. The views echo the realities of Kaji's Reportage of Peace Village, which was presumably the best source for Kaji to grasp the situation of late 193os wartime Japan proper. The first brother, Ichirō, works long hours at a factory and takes care of his sick mother together with Mitsuko, the wife of the second brother. The second brother, Jirō, is fighting in the war against China. The third brother, Saburō, is an antiwar activist who must hide in order to avoid arrest. The war has torn the Miyamoto family apart and each brother tries to survive in his own way.

Despite the initial language barriers, ${ }^{64}$ the media attention and the support of many prominent cultural figures played a significant role in promoting Kaij's

62 After Guilin, the actors performed Three Brothers at several venues in the region. However, after a performance in Chongqing, the GMD canceled the remaining shows as a result of growing worry for communist expansion in the GMD occupied areas and the deteriorating relationship between the GMD and CCP.

63 The two Chinese translations, by Xia Yan and Ouyang Yuqing (1889-1962), have survived, but the original Japanese script seems lost. Besides a Chinese translation, the Esperantist and polyglot Ye Junjian (1914-1999) translated the script in English for the Soviet journal International Literature.

64 As the actors were members of the Antiwar League, they performed Three Brothers in Japanese for a mostly Chinese audience. To overcome the language barrier, Ouyang was the first to translate the script of Three Brothers. Requested by the Chinese director, Ouyang had to rush to finish his translation. His translation was used for the Chinese staff and actors as well as made into a mimeograph used to play during the performance to provide a Chinese translation for the audience. See Ouyang Fanhai [Yuqian], 'Yiwan Sanxiongdi yihou,' Xiandai wenyi 1, no. 1 (1940): 137. Ouyang's translation was published in the journal Yilin in 1940, and the afterword to Ouyang' translation by Lou Shiyi (1905-2001). Lou Shiyi, 'Houji,' Yilin 1, no. 1 (1940): 155 . 
work. Feng Naichao praised the work for deepening the understanding of the war by showing the multiple sides of the Japanese and that not all Japanese support the war, but are actually part of the resistance movement. ${ }^{65}$ Hong Shen valued the authenticity of the play's actors, as they had served in the war as both Japanese soldiers and antiwar activists. ${ }^{66}$ Lastly, translator Xia Yan wrote a recommendation stating that "[Three Brothers] is a valuable addition to the theater establishment, because [the story] is authentic (zhenshi) and conveys everyday life completely (quan shi shenghuo), 67 echoing the aspirations of reportage literature. While Feng, Hong and Xia understood Kaji's intentions, Ouyang critiqued Kaji's Three Brothers for lacking any description of the war and neglecting any reference to the situation in China proper. As part of the roundtable, he said that 'any mentioning of the shared oppression of Chinese and Japanese is absent [in Three Brothers].'68 Kaji, however, chose to depict the Japanese soldiers and citizens in their everyday life, as opposed to the battlefield described in the majority of War of Resistance literature, in order to demonstrate that the majority of Japanese soldiers did not volunteer to fight, but were forced onto the battlefield by conscription. Moreover, he believed, after completing several interviews with Pows in Peace Village and his observations at the frontline, that these soldiers also were neither imperialist nor fascist. They were just regular people forced into a war due to circumstance. Kaji wrote that 'the purpose of the play is to have the Chinese government and people understand the situation of the Japanese people and to promote a friendship based on our shared destiny. ${ }^{69}$ This 'shared destiny' thus implies that the home front depicted in Three Brothers is deeply connected to the 'shared oppression' Ouyang refers to. In contrast to the struggle of Japan's wartime propaganda to unify the battlefront with the home front, ${ }^{70}$ Kaji managed to demonstrate that the ubiquitous violence through various manifestations in pow camps, battlefields, and home fronts were all intricately connected.

65 Quoted in Inoue, Chūgoku de hansen heiwa katsudō o shita Nihonjin, 112.

66 Quoted in Kikuchi, Nihonjin hansen heishi to nitchū sensō, 81.

67 Xia Yan, 'Wo tuijian zhege juben,' Jiuwang Ribao, March 14, 1940. Reprinted in Kaji Wataru shiryō chōsa kankōkai hen, Nihon jinmin hansen dōmei shiryō, vol. 9 (Tokyo: Fuji Shuppan, 1994), 335 .

68 Ouyang Fanhai (Yuqian), 'Jieshao yu piping: Sanxiongdi zuotan jilu,' Jiuwang Ribao, March 14, 1940. Reprinted in Kaji Wataru shiryō chōsa kankōkai hen, Nihon jinmin hansen dōmei shiryō, vol. 9 (Tokyo: Fuji Shuppan, 1994), 335.

69 Kaji, Chügoku no jūnen, 129.

70 Kushner states that the main goal of Japan's wartime propaganda was the unification of the battlefront with the home front. Kushner, The Thought of War, 6 . 
Although Ouyang critiqued Three Brothers for the absence of battlefield scenes, the play did have a latent presence of war throughout the narrative consistent with Kaji's attempt to present distant geographical spaces as interconnected. Lacking any graphic imagery common to the war violence depicted in (anti)war novels, the war in Three Brothers appears in various other forms that shape the daily lives of the characters. For example, the absence of letters for three months (excluding the letter that the mother forgets to open due to illness), highlights the lingering anxiety the family feels about the safety of Jirō on the front. The only material connection to Jirō mentioned is a photograph of him taken before his departure to the front. When the rent collector staring at the photograph asks if the family received any correspondence from Jirō, the mother avoids his questions, not willing to talk about her son. The war has changed the meaning of the photograph from a last memory of Jirō's physical presence to a trigger for the fear and pain of loss. In other words, after Jiro's departure to the front, war has directly penetrated the Miyamoto family, incorporating them into the realm of war. While the Japanese propaganda was confronted with the challenge how to link the battlefront with the home front due to the absence of the enemy at home necessary 'to inculcate hatred against [the enemy], ${ }^{71}$ Kaji envisioned that the opposite, a shared pain between the battlefront and the home front, would bring the two closer.

With Ichirō being the only brother at home, the Miyamoto family struggles to make ends meet. The factory requires him to work long hours to supply the war demands, while his salary is decreasing. The family is behind on the rent by three months and is short on money to purchase any medicine for the sick mother. During work, the rent collector visits the family, pressuring the sick mother to pay. He refuses to listen to the mother's excuses for not being able to pay the rent. When Ichirō returns from work to tell the rent collector once again that they do not have enough money, the rent collector angrily compares him with 'the Chinese resistance strategy of protracting war'. It is only when Ichirō's colleagues A and B visit the house, the rent collector discontinues his intimidation due to an argument between the two colleagues.

B: They always say that if you are going to war there is no need for the family to worry. However, the home front is the same as going to war! A: In the current war, the home front is the original battlefield. For example, the men of this family are off to war, their mother is sick, the daughter-in-law is pregnant, but she still needs to work. Eventually, this is how they lose their lives. Haven't they suffered enough? Miyamoto is very 
pitiful. When his little brother was sent to the war, we said it too, 'don't worry you have us'. But now we all have to help them. Now the home front resembles the battlefront. If the families of honored soldiers have no house to live in, then don't we all have some responsibility? If your rent collecting boss had a good heart, then there wouldn't be any problem. ${ }^{72}$

Ichirō's two colleagues compare the battlefront and home front, and conclude that both are the same. They suture the spatial gap between the two as one because the battlefront affects the home front profoundly. The hardships experienced by a family, such as the Miyamoto's, are a direct result of the war, yet any opposition or complaint is met with punishment by the government. What remains for them is to help each other as 'comrades'. Kaji shows readers (and spectators) how a war seemingly absent from the narrative is actually present in the everyday lives of the Miyamoto family.

The situation for the Miyamoto family worsens when an officer informs them about the death of Jirō. Immediately before the officer's visit, the sick mother remembers she received a letter from Jirō dated three months ago and hands it over to Mitsuko. Reading the letter, Mitsuko learns about Jirō's fear felt at the battlefront and the loss of his fellow soldiers. Jirō's letter breaks down the spatial gap between the battlefield and home front resembling A and B's idea of the two being the same. The direct experience of war violence enters the daily lives of the Miyamoto family vividly. The letter, however, also provides hope to Mitsuko informing her of Jirō's being alive. She even wishes she could go to the battlefield, thinking: 'suppose I was a man then when two people are together surrounded by grenades, we wouldn't die a lonely death. ${ }^{73} \mathrm{Her}$ hope is soon crushed when the officer brings the news of Jirō's death. Similar to the photograph, the violence of war contained in the message of the officer transgresses the battlefront and merges with the home front. The act ends with a clerk bringing a conscription order for Ichirō, taking away the last son of the sick mother. The character A ironically retorts: 'this is war'.

Three Brothers compresses all the drama inflicted upon the Miyamoto family consecutively without any temporal markers (other than a year) in the text, diverging from the reality sense and longitudinal description of reportage. The abundance of melodrama, however, still manages to exacerbate the abjection towards war suitable for theater. The violence imposed by the government,

\footnotetext{
72 Kaji Wataru, Sanxiongdi [Sankyōdai], translated by Xia Yan (Shanghai: Xiju Shudian, 1940), 26. A year later, Nanfang Chubanshe in Guilin published a second edition.

73 Ibid., 34.
} 
forcing Japanese proletarians into the army, as well as putting the weight of the economic burden on them, forms the crux of the play. By exposing the forced nature of the Japanese imperial army, which is censored in Japan and unknown in China, Kaji hopes that the Chinese audience will show solidarity with the Japanese soldiers and welcomes them to join the anti-imperial and antifascist resistance.

In the final act, Ichirō engages in an act of antiwar resistance, which symbolizes Kaji's wish to have the Japanese join the antiwar movement. The next day, everyone gathers to see Ichirō off. His mother shows no sign of support for the war and advises Ichirō 'not to care too much about winning and just try to avoid the bullets'. Then, the third brother, Saburō, suddenly appears after he heard about Jirō's death and Ichirō's conscription. He worries about the fate of his sick mother when Ichirō leaves and aims to persuade him to ignore the conscription order. Then, the police, who must have followed Saburō, arrives and shoot him. While Saburō falls to the ground, struggling to stay alive, their sick mother is overwhelmed with shock and grief. All the unimaginable bad luck strikes the Miyamoto family in that moment. Ignoring Jirō's suffering, the officers try to take him away for conscription, but Jirō refuses. He loses his temper and the plays end with Jirō shouting:

I oppose how they let people endure the hardships of war. For the sake of invading another country, they displace farmers of the entire country. So eventually who is fighting the war? Let those guys go to war. What 'Hooray, hooray' I can't go anymore. Just arrest me. (He sits on the street with both hands crossed.) I have awaken. My brother wasn't wrong. Are you gonna beat me just like you beat him? Just arrest me. Fuck. I oppose the aggressor war. And for those who don't get this truth, just as I didn't, until your entire family dies. Let's shout Hooray, hooray. Let me go out and call the police to come! Call those dogs to come! ... Oppose the aggressor war! ${ }^{74}$

\section{Conclusion}

In 1941, the GMD forced Kaji to disband the Antiwar League following the deteriorating relationship between the GMD and $\mathrm{CCP}$ and growing fears about communist infiltration within the GMD region. The GMD grew suspicious of Kaji, 
accusing him of 'anti-Kмт[GMD] beliefs.' ${ }^{75}$ During its three-year existence, the Antiwar League under Kaji expanded to several hundred members active in the Southern regions of China. In addition, the Antiwar League acted as the beacon of hope for numerous Japanese antiwar organizations established across China. Together, they became an important part of the resistance movement against Japanese imperialism and the international united front against fascism. Actively involved in educating pows and persuading soldiers to desert, Kaji's cultural production was formative for his anti-imperialist visions, which contributed significantly to the popularization and internationalization of the War of Resistance Movement in China. For Kaji, reportage and literature had the power to bring seemingly disparate locales and contexts together into a shared story of international resistance against fascist oppression. After Japan's defeat, Kaji returned to Japan where he continued his political activism until his death in 1982.

As this paper has shown, Japanese antiwar and antifascist intellectual history did not end with the opposition in Japan proper during the early 193os but continued outside the archipelago through the 1930s and early 1940s by activists like Kaji and his Antiwar League. Expanding our scope from a national to a global perspective, Kaji's activism reveals how on the fringes of the Japanese empire an international united front of antiwar and antifascist resistance thrived at undermining fascist ideology, through the use of cultural works that disseminated antiwar propaganda to various audiences. While previous studies have begun to include Kaji in the history of antiwar activism, the content of his cultural production has remained largely untouched. Therefore, examining Kaji's cultural production central to his antiwar activities in China and the main medium through which he articulated his antiwar and antifascist thinking provides us with a fuller understanding of the history of Japanese and international antiwar activism.

\section{Acknowledgements}

An earlier version of this article was presented at the 28thAnnual Graduate Student Conference on East Asia at Columbia University in 2019. I thank the organizers for these opportunities, and those who attended the session. I was fortunate to receive invaluable comments and suggestions on earlier drafts from my peers Alexandre Paquet and Mark Lush, my editor Lisa Pfau, and my supervisor Dr. Atsuko Sakaki. Last but not the least, I thank my anonymous reviewers and the journal editors Mattie Fitch, Nicholas Underwood, and Michael Ortiz for extensive comments and insightful advice.

75 Kushner, The Thought of War, 142. 